\title{
How Does NATO Apply Instruments of Power as it Prepares for the Possibility of Conventional Warfare Against a Peer Adversary? Applying a 'DIMEFIL' analysis.
}

\section{Ronald Ti}

This article examines the question of how NATO employs instruments of power as it prepares for a possible defence against aggression from a potential adversary. It will attempt to answer this question by applying the various instruments of national power to form a qualitative assessment of the degree to which NATO exerts itself in these those power domains and how effectively these prepare NATO for conventional warfare. The article will consider how these instruments of national power, as represented by the 'DIMEFIL' acronym, can be applied and quantified as NATO's own 'supranational' power parameters. Notwithstanding the obvious fact that NATO cannot be considered as a 'national' entity, nevertheless this article argues that such an analysis provides sufficient validity to produce observations and derive reliable conclusions. Whether such an analysis can shed light on NATO's level of preparedness in fighting- and winning- a conventional European land conflict is the principal consideration of this article.

The question addressed in the title of this article represents one of the main challenges facing the North Atlantic Treaty Organisation (NATO) in 2021. Recent events occurring in Eastern Europe and Russia have forced NATO back into its primary Cold War role as a defensive, collective military alliance, revealing Fukuyama's 1989 annunciation of the 'final triumph' of 'western liberalism' to be premature, unrealistic, and fuelled by unfounded optimism (Fukuyama, 1989). In fact, the 'democratisation' of the entire planet now seems even more distant. The period between the fall of the Berlin Wall and growing Russian rejection of Western integration, as typified by Russian president Putin's February 2007 Munich Security Conference speech, has indeed turned out to be an interregnum period.

NATO's military activities in the period between the dissolution of the Soviet Union and the 2014 Russian coup de main in Crimea have consisted in the main of either airpower use without a substantial commitment of ground troops (Serbia and Libya), or the commitment of ground troops in post-conflict situations (Bosnia-Kosovo), or as part of intrastate stabilisation missions. NATO's 13-year commitment from 2001 in Afghanistan in the form of the International Security Assistance Force (ISAF) is a prime example of the latter. This particular deployment stretches the credibility of any rationale related to collective European defence, but rather suggests underlying compromises more related to wider Euro-Atlantic political considerations. In addition, NATO's activities have been undertaken against various adversaries such as the Taliban in Afghanistan or Serbia in the Balkans, who, despite being 
able to strike back lethally at tactical levels, could not be regarded as possessing anything like equivalent conventional military capabilities. In summary, since its inception in 1949, NATO has yet to engage in high intensity, high lethality, major joint warfighting against a peer or near peer adversary.

The situation has now changed radically for NATO, with the alliance now facing the possibility of conducting major joint operations in Europe against an equivalent, nuclear armed adversary. In this context only one single regional state actor, the Russian Federation, could possibly be considered a 'peer' or 'near-peer' adversary possessing the prerequisite military capability necessary to engage NATO in conventional warfare within the Alliance's primary European area of operational responsibility. Furthermore, NATO is assuming many of its former 'Cold War' areas of responsibility in a security environment many times more complex than the previous 'binary' situation of 'NATO versus the Warsaw Pact'. As the possibility of great power conflict re-emerges on NATO's eastern border, the Alliance's collective ability, preparedness, and political will to fight a conventional war against Russia has now been thrown into very sharp focus.

\section{Conventional warfare: no nukes}

This paper will define 'conventional warfare' in terms of armed engagement between NATO and Russian militaries utilising all means up to, but not including both limited yield and strategic nuclear weapons. Each side has deployed a number of ground-launched (so-called) 'tactical' nuclear weapons in continental Europe on a longstanding basis. In the case of NATO, this amounts to approximately 150 warheads located in five NATO member states (SIPRI, 2020). The exact number of equivalent Russian systems is unknown. It should also be noted that in distinction to NATO deterrence doctrine, an intrinsic part of Russian doctrine is a nuclear 'escalate/de-escalate' policy, and unlike the case in NATO exercises, Russian military planners routinely incorporate the active employment of limited yield nuclear weapons as integral parts of major exercise scenarios, as in the 2017 'Zapad' series (Boulegue, 2017. Johnson, 2017). The discussion presented in this paper will exclude any discussion of the use of nuclear weapons and will confine itself to conventional, non-nuclear warfare only.

\section{Applying the 'DIMEFIL' metrics as instruments of supranational power: the dimensions of NATO preparedness.}

The seven principal instruments of national power are summarised by the 'DIMEFIL' acronym. These letters correspond to the following domains, viz: Diplomatic, Informational, Military, Economic, Financial, Intelligence sharing, and Legal. Since its appearance in 2006, the DIMEFIL acronym has gained wide acceptance and is now in wider general use than the earlier and shorter 'DIME' acronym (Bartholomees Jr et al, 2012). ${ }^{1}$ Of note is the inclusion of the 'legal' category, recognising not only the important role of legal process in legitimisation of potential defensive International Armed Conflict, but also in its increasing 'weaponisation' in contemporary warfare (Oskarsson 2017). It should also be noted from the outset that whilst DIMEFIL is commonly understood to represent the instruments of national power and recognising that NATO as a collective entity is a 'supranational' and not national entity per se, this paper argues that these same instruments of power can be validly applied to NATO in order to make a qualitative assessment of its levels of preparedness.

\footnotetext{
1 'DIMEFIL' is the preferred term in current US War College instruction.
} 
This paper will analyse and discuss NATO's current preparedness to engage in conventional war against Russia according to each 'DIMEFIL' category. What will be readily apparent as a result is that NATO's capability varies widely across these 'supranational' instruments of power. As one example, aside from a prominent public advocacy role, NATO itself lacks any form of diplomatic power instrument. The same statement can also be made with respect to the financial instrument of power, with NATO lacking any real capability in this dimension. This article argues that NATO's 'supranational' power, and hence preparedness, is somewhat lopsided. Whilst it is manifest strongly in some areas (i.e.: military), it is all but absent in others (i.e.: diplomatic and financial instruments of power, as described above).

An important caveat prior to commencing this analysis is the fact that NATO's capability for conventional warfare is wholly dependent on the capability of individual NATO member states and their respective levels of preparedness and readiness. As an entity, NATO itself lacks coercive military capability of any kind: in essence 'NATO' is essentially an aggregation of headquarters and multiple associated departments. Notwithstanding this, the essay will synthesise and present a 'NATO wide' assessment, mindful of the fact that NATO 'capability' as such is comprised entirely of the net, cumulative capabilities of the Alliance's twenty-nine member states. In truth, 'NATO' of itself has no capability of its own; this essay will use the term 'NATO capability' as a synonym for the collective alliance capability of member states engaged under a NATO coalition command structure.

\section{Diplomatic, economic, and financial instruments of power}

NATO possesses considerable notional diplomatic influence, but little actual positional diplomatic power. This is expressed principally through the advocacy of the NATO Secretary General. NATO 'dialogue diplomacy' itself consists of the net expression of resolutions and decisions reached collectively-and unanimously-by the twenty-nine NATO members of the North Atlantic Council. NATO in itself cannot undertake any form of diplomatic sanction, let alone the most fundamental adverse diplomatic action such as the expulsion of foreign officials. Lacking true sovereign diplomatic power, by definition, NATO must defer to the national actions and intent of its individual member states. In this instance no actual NATO diplomatic 'preparedness' is possible. In a similar way to diplomatic dimensions, NATO cannot enact economic measures such as sanctions or financial embargoes. The exercise of these instruments of power are entirely in national hands and are hence entirely divested to individual NATO member states. As a contrast, the other European collective to compare with NATO is the European Union (EU), which exercises relatively greater discretionary power when acting as a bloc in the diplomatic, economic, and financial domains of power. However just like NATO, EU power remains intrinsically vested in nations. At the same time, the EU has currently little to no military instrument of power when compared to NATO. Thus, for example, the 2021 EU Battle Group (EUBG) was relatively much smaller and less developed when compared to NATO's Very High Readiness Joint Task Force (VJTF).

In summary, NATO's intrinsic preparedness for a future conflict in the diplomatic, financial, and economic dimensions is largely non-existent and wholly dependent on the capabilities, intent, and national interests, of individual NATO member states. 


\section{Informational instruments of power}

To win one hundred victories in one hundred battles is not the acme of skill. To subdue the enemy without fighting is the acme of skill.

\section{Sun Tzu 'the Art of War'}

NATO possesses substantial 'informational' capabilities in the area of public affairs (both civil and military), public relations, a well-developed social media presence, and a highly credible and trusted profile in general public discourse. These act collectively to disseminate NATO's public messaging, with the broad message being the promotion of NATO's 'dual track' approach. This approach emphasises on one hand NATO's military deterrence whilst on the other emphasises ongoing NATO dialogue and promotion of arms control initiatives. An important but often unstated component of this is NATO's 'soft power', which is closely linked to Western European democratic values: these stand in stark contrast to Russian 'soft power'.

At the same time as NATO informational activities, substantial 'inform and influence' activity is also occurring from the Russian side. These Russian 'information operations' are far more active, obtrusive, and offensive, and encompass a wide range of activities manifested in a variety of ways and means. These include not only cyber-attacks, 'hacker' attacks, and intense media messaging, but also activities aimed at securing political influence. For example, recent attention has been focussed on Russian funding of pro-Russian, European political parties which include Jobbik in Hungary (Gyori, Kreko, 2017) or the Front Nationale in France (Sonne, 2018). These actions targeting NATO member states at higher national levels speak to the breadth of Russian use of the informational instrument of state power. Even recent Russian cyber-related actions such as the alleged use of 'bots' delivered via 'Twitter' accounts attempting to sway public opinion in key 'swing seats' during elections represent a significant escalation of offensive Russian informational action/ information operations. The overall aim is to undermine NATO's unity by utilising a range of actions which lie below conventional thresholds for warfare and conflict. Such activities have been termed 'grey zone' conflict, acknowledging the reality that whilst both war and peace are 'black and white' states, most activity occurs in the wide and ambiguous 'grey zone' (lying between these two diametrically situated absolutes) where competition and conflict simultaneously co-exist. (Connable B. et al, 2020) Cracks and fractures across the Alliance are well publicised with frequent comments by former US President Trump only eroding European confidence in American resolve. If NATO willingness to go to war over, say, Estonia were undermined, this would represent a considerable victory for the Russian Federation. As the opening quotation to this section attest: the sweetest victory is one where no fighting need occur, nor blood be spilt. In the case of Estonia, this may manifest as European indecision as to the course of action to be taken. It is in Russia's absolute interest to undermine any given individual NATO state's commitment to accede to their collective defence commitments. Disruption of NATO member state resolve and unity is the 'sought-after' decisive outcome of Russian information operations, and a fundamental risk to NATO arising from the informational space. Executed properly, the exercise by Russia of its informational instrument of power may indeed eventually result in a war being won without a single shot being fired. This would occur if , say, a Baltic state's sovereignty was violated by a limited Russian incursion to which certain NATO members would simply choose not to respond. An example could be Russia 'biting off' a small piece of Estonian territory and then simply stopping. In this case, some NATO members would consider this an armed attack triggering Article $\mathrm{V}$ obligations; others, perhaps 
more geographically distant NATO members, might well not. To paraphrase Sir Neville Chamberlain's 1938 remarks on Czechoslovakia, it would suit Russia if , say, such a Russian incursion in the Baltics was viewed by more distant NATO members as a '...quarrel in a faraway country, between people of whom we know nothing...' (Chamberlain,1938) and in which any armed intervention on the part of that NATO member would be out of the question. This is one end that is being sought by Russian application of the ways and means briefly described here, activities aimed at undermining NATO unity and collective resolve.

In comparison to well-established Russian offensive activity in the cyber domain, NATO has only just begun to operationalise cyberspace in ways above merely passive cyber defence (Lewis, 2019). Furthermore, whilst Russian cyber and hacker activity is clearly offensive in nature, given that NATO also possesses similar capabilities, clear decisions have yet to be made at the higher NATO policy level linking its overall strategic policy with this incipient cyber policy. This includes clear higher direction on not only undertaking, but initiating, offensive cyber operations. Until this most fundamental alignment of NATO cyber policy with strategic intent is completed, NATO's ability to express its informational instrument of power will continue its present state of strict limitation to reactive (and largely inadequate) defensive measures (Veenendaal et al, 2016). In concluding this section, it should be noted that its focus on Russia's informational instrument of national power stands in contrast to NATO's current lack of initiative in employing this particular instrument of power, primarily due to a certain degree of strategic incoherence regarding its use

\section{Intelligence sharing as an instrument of power}

Closely linked to its intrinsic lack of independent capability, NATO cannot in itself exercise its intelligence instrument of power as 'NATO' intelligence is derived almost entirely from what is gathered, analysed, and provided by individual NATO member states at their sole discretion. Notwithstanding this, renewed efforts at improving the integration of national intelligence gathering and analysis at the supranational NATO level in order to benefit the 'NATO whole' have recently received endorsement at the highest levels (NATO Brussels summit declaration,2018). A Joint Intelligence and Security Division (JISD) co-located with NATO Headquarters in Brussels has been established since 2017. Enhanced civil and military intelligence cooperation has also reportedly improved (Freytag von Loringhoven, 2019). Additionally, NATO as a whole benefits somewhat from the fact that three NATO member states (the USA, the UK, and Canada) are also part of the Anglosphere 'Five Eyes' intelligence sharing network. ${ }^{2}$ This is likely one of the most comprehensive international intelligence networks in current operation, however a significant caveat here is that intelligence sharing will always be at a higher level between the 'Five Eyes' nations, when compared to other, non 'Five Eyes' NATO members.

\section{The legal instrument of supranational power and 'Article V'.}

NATO was created in 1949 by the signing of the North Atlantic Charter ('the NATO charter') by twelve founding states. Article $V$ of this NATO charter is the principal legal justification for NATO's collective defence and states that: '...The Parties agree that an armed attack against one or more of them in Europe or North America shall be considered an attack

\footnotetext{
2 The remaining two 'Five Eyes' members are New Zealand and Australia. The latter has entered into an exclusive 'Individual Partnership and Cooperation Program' with NATO from 7 August 2019, giving Australia the closest relationship, aside from NATO membership, of all non-NATO nations (including the PfP bloc).
} 
against them all...' (NATO Treaty, 1949). The original UN Charter (UN ,1945) sets out two fundamental rules governing the security of NATO member states. One is in the prohibition of the use of aggressive force, being a fundamental principle that summarises much of the vision of the UN Charter for a peaceful, civil, international community. This is expressed principally in Article 2, subparagraph 4 of the UN Charter, part of which reads:

(all) members shall refrain in their international relations from the threat or use of force against the territorial integrity or political independence of any state, or in any other manner inconsistent with the purposes of the United Nations (UN, 1945).

Article 2, paragraph 4 is a key provision in international law and '... is regarded ...as a (fundamental) principle of customary international law and as such is binding upon all states in the world's community...' (Shaw, 2017).

The second concerns the right to individual and collective self-defence and is described in Chapter VII, Article 51, of the UN Charter. This provides for the right of a state (or, importantly, a collective defensive security alliance such as NATO) to defend itself from external attack. Part of Article 51 states: '...nothing in the present Charter shall impair the inherent right of individual or collective self-defence if an armed attack occurs against a member of the UN...' (UN, 1945). UN Article 51 is replicated in Article V of NATO's North Atlantic Charter. Aligning Article $V$ of the NATO Charter with the UN Charter not only links both the UN Charter and the North Atlantic Charter with a widely accepted foundation of international law but also legitimises NATO's defensive use of force in any potential International Armed Conflict. NATO Article V hence confers legitimacy under International Law because it is anchored on internationally accepted norms under which states have rights to enter a conflict in order to defend themselves. This is termed 'jus ad bellum'.

International law thus provides the critical legal underpinning of NATO's Article V collective security arrangement. This sound basis of international law which underpins NATO's Article V collective defence provisions represents substantial legitimacy. It is this very legitimacy which comprises the ethical and moral basis that is essential in marshalling both the forces and the public support needed to sustain a collective alliance such as NATO. It is of note that legitimacy is a vital element that is sought after by governments of all persuasions to justify state action, whether such reasons are real, constructed, or both. In Russia's case, it regularly manipulates both international and domestic law in order to manufacture pretexts to justify its actions. The 2014 Russian annexation of Crimea is a case in point, where it attempted to legitimise its actions first by recourse to International Human Rights law, claiming that an extra-territorial intervention was necessary in the interests of the 'Protection of Civilians' (POC) within the territory of Crimea. It then legislated to make Crimea itself domestic Russian territory, converting the ' $P O C^{\prime}$ mission into an internal Russian law and order matter (Voyger, 2019). This illustrates the process whereby law is manipulated to suit state ends without reference to objective internationally established norms and has been termed 'lawfare' by a former US Judge Advocate General (Dunlap, 2001). The same need to intervene to protect human rights of 'persecuted minorities' has been identified as a potential provocation for Russian action in the Baltics in support of sizable populations of ethnic Russians living in these countries. The self-same type of justification was used by the German government to justify its 1938 annexation of the Sudetenland, in which the basis for the rationalisation and deception was much the same. 'Lawfare' will continue to play an 
important part in justifying state action by whichever side chooses to employ it as an instrument of power.

Finally, it is important to note that despite the many reassurances and statements of NATO member nations, any future incident triggering an Article $V$ situation does not necessarily mean that a unified NATO would automatically go to war. Article $V$ is a negotiated statement of intent: an extraordinary meeting of the twenty-nine member North Atlantic Council is first required, and an Article $V$ situation unanimously agreed to. Then, and only then, could NATO's collective defensive measures be brought to bear. Despite the existence of measures such as 'Fast Track Accelerated Decision Making' and pre-determined 'Crisis Response Measures' both contained within NATO's response mechanism, North Atlantic Council agreement must first occur for any substantial NATO collective defensive response. It is especially in the process of influencing the resolution of NATO member states that power projection in the form of the information dimension of power becomes of particular relevance and was discussed in a previous section.

\section{NATO military capability is functionally a 'single' entity.}

As previously discussed, despite the fact that NATO as an entity itself possesses insignificant military force, this essay will consider NATO's collective military capabilities as a single, discrete entity. It is worthwhile to consider briefly at this point why such a generalisation is possible when considering the military instrument of power, when for most of the other instruments of power this generalisation does not hold. In NATO's situation, the major differential in the case of what is functionally a military instrument of 'supra' national power is the existence of well-established long-standing, NATO collective Joint Force command structures. This consists of a number of component commands, principally located in Naples, (ITA) Brunssum (BEL), UIm (DEU), and Norfolk (USA). In addition, NATO has higher echelon land, maritime, and air component commands located in Izmir (TUR), Northwood (GBR), and Ramstein (DEU), respectively (NATO, 2017) Hence despite the fact that contributing NATO member states provide the entire functional components of NATO capability, due to these NATO military command structures, and the fact that individual NATO states have consented to assign their forces under an operational control arrangement to an overall NATO command, the result -to a certain extent- is that of uniting the various and diverse NATO military force elements. This functional collaboration permits NATO military preparedness to be discussed in this article as a single functional entity. Whilst in actual fact this summation is not entirely accurate, for the purposes of this document this is a functionally valid assumption on which to proceed. Nevertheless, it is important to always bear in mind that the primacy of national command over collective NATO authority is always firmly in place, with sometimes adverse effects on overall NATO intent. An example of the primacy of national over 'NATO' collective authority occurred during the October 2005 Pakistan earthquake when the deployment of the NRF was cancelled after several NATO states withheld their consent, citing primary concerns over national security issues as opposed to collective Alliance commitments (as occurred in this instance where the issue did not directly concern collective defence).

\section{The military instrument of power}

NATO was created in 1949 as a collective military alliance for the defence of Europe in the event of an invasion by the Soviet Union a mission which persists to this day, and in 2021 NATO is first and foremost a collective military alliance. The exercise of the military 
instrument of power is therefore NATO's core business and it is in the domain of military power where the greatest requirement for NATO preparedness exists. (It should be noted that the terms 'preparedness' and 'readiness' will be used interchangeably from this point in the article). 'Preparedness' is a broad concept that is somewhat difficult to define, and to make an adequate assessment requires:

A comprehensive view that takes into account both the operational and the organisational, or strategic, perspectives. At the unit level, readiness is about equipment, manning, training, and interoperability. At the organisational level, readiness can be simply defined as 'the ability of military forces to fight and meet the demands of assigned missions (Hill, 2019).

NATO's total military preparedness is hence a complex topic, with anything approaching a comprehensive analysis well beyond the scope of this article, which will limit itself mainly to an analysis of NATO's preparedness at the strategic level. Relevant factors related to operational levels of war will be included. Tactical level considerations such as comparisons of individual weapon systems, training, unit organisation, etc, are well beyond the boundaries of this article and will not be discussed here.

From the outset, Russia enjoys three key military strategic/ operational advantages over NATO. According to a recent authoritative NATO commentary, these can be listed as:

1. Its regional military superiority in areas close to its borders with NATO territory;

2. its ability to quickly mobilise and move massive numbers of conventional forces across Russia's vast territory, and 3. its capabilities to deny, disrupt or complicate NATO's reinforcement options, including with intermediate- and strategic-range strike capabilities. (Durkalec, 2019).

To these four key points can be added the critical roles of reinforcement, sustainment, movement, and host nation support This article will now discuss each of these points in turn, in particular paying attention to how NATO currently exercises its potent supranational instrument of military power at both strategic and operational levels of war to enable preparedness. The risk mitigation that NATO may have to undertake resulting from with each perceived advantage on Russia's part will also be discussed.

\section{Russian regional military superiority in areas close to its borders with NATO territory and its ability to quickly mobilise and move massive numbers of conventional forces across its territory relatively quickly.}

The dual elements of Russian local superiority and access are direct consequences of geography. A major current NATO area of concern are the three Baltic states of Lithuania, Latvia, and Estonia. These NATO member states which face Russia over a $500 \mathrm{~km}$ frontage, with an additional $500 \mathrm{~km}$ formed by the Belarussian border. In addition, Lithuania has a border with the heavily fortified Russian enclave of Kaliningrad oblast, thus giving it direct Russian borders to both the southeast and west. Other NATO member states such as Poland, Turkey, USA, Canada, and Norway, also share borders with Russia. 
Reinforcement of the Baltic states is made challenging by a narrow space of land known variously as either the Suwałki 'Gap' or 'corridor'. It is through this narrow $115 \mathrm{~km}$ wide 'gap' that NATO land forces must traverse in order to reinforce the Baltic NATO member states in the event of a situation triggering Article V (Hodges et al, 2018). It should be noted that substantial anti-access/ area denial assets are in place, particularly situated in the Kaliningrad oblast, sufficient to present significant challenges to both naval and aerial NATO forces. The present 'Enhanced Forward Presence' (EFP) NATO deployment in the Baltic states was initiated after the 2016 Warsaw summit in direct response to Russian aggression against Ukraine. EFP places token NATO ground and air forces directly in all three Baltic NATO states. These are insignificant militarily when compared to those of the opposing Russian Western Military District but have been placed as a 'tripwire' force. They therefore act as a highly significant representation of NATO intent to defend the Baltics. Notwithstanding the direct NATO EFP presence, recent opinion polls in certain NATO member states show low levels of public support for commitment of forces in the event of an Article $V$ situation- particularly in the Baltics. The opinion that NATO states may dishonour their Article $V$ obligations and stand aside in a Russian attack on Estonia is not an uncommon one and has recently been expressed by a number of prominent defence commentators (Simpson, 2016). This final point yet again reinforces the importance of the Information dimension of power (as discussed previously) and its potential to undermine the resolve of individual NATO member states and their respective populations.

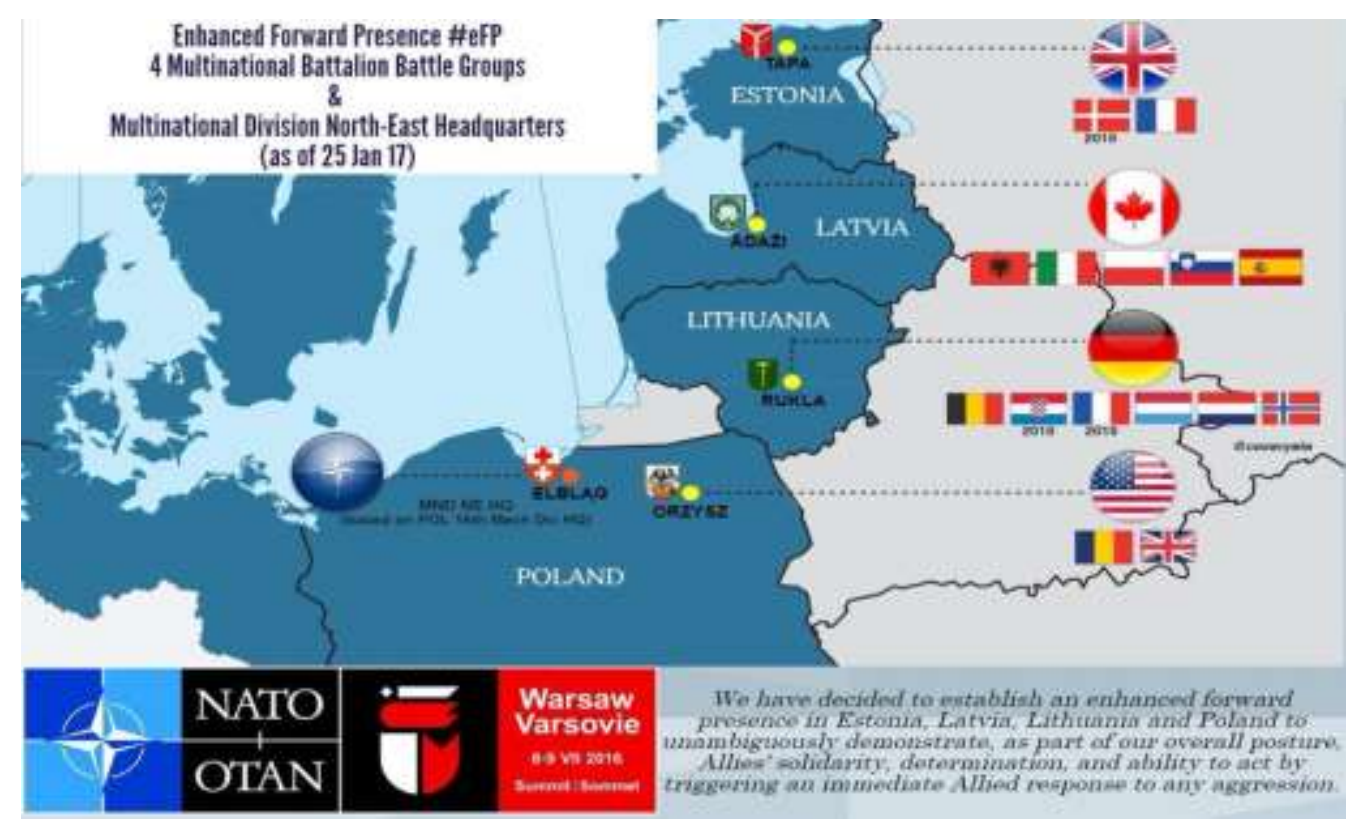

Figure 5: NATO's response to Baltic geopolitics: The Enhanced Forward Presence (EFP).

The flags represent the various NATO nations contributing forces at that point, with overall leadership in the Lithuania, Latvia, and Estonia states being vested in the three lead NATO Nations of Germany, Canada, and Great Britain, respectively. (Source: (c) 1996 - 2021 The Baltic Course., reproduction for fair use, all rights reserved, required hyperlink: :www.baltic-course.com.)

The deployment of standing NATO military forces to the Baltics, an action which would have been inconceivable only a few short years previously, is one measure of NATO 
preparedness in exercising deterrence in the face of a potential conventional war with a peer adversary such as Russia. Other NATO preparedness initiatives in the same vein have included placing a greater emphasis on building a NATO Response Force (NRF), the parameters of which were also clarified after the 2018 Warsaw NATO summit. A Very High Readiness Joint Task Force (VJTF) built on force elements located in the eastern NATO states has also been raised since 2018.

\section{Russia's capabilities to deny, disrupt or complicate NATO's reinforcement options, including with intermediate- and strategic-range strike capabilities.}

A significant advantage Russia enjoys is its ability to pre-emptively interdict NATO lines of communications well beyond its frontline borders. This includes the ability to threaten every major Western European population centre with substantial numbers of ground-launched missile systems. Russia's violation of the Intermediate Range Nuclear Forces Treaty (INF) in 2017 with its covert deployment of SS8/9 M729 Intermediate Range ground-launched Cruise Missiles was a 'signal' event marking a significant adverse turn in NATO-Russia relationships (Gordon, 2017). This act placed every major European population centre not only within the range of Russian missiles capable of carrying either conventional or nuclear warheads, but also subject to a weapons system that could launch below conventional strategic missile detection thresholds, effectively enabling a potential Russian surprise 'first strike' in Europe. That development of the SS8/9M729 could only have occurred covertly whilst the INF was extant only added to NATO-wide dismay at this Russian treaty violation. Quite aside from their potential to deliver nuclear warheads, by carrying conventional munitions, these weapon systems can also interdict NATO movement and strike targets of military value, such as rail junctions and major bridges, literally anywhere within Western Europe. This 'Anti-access/ Area Denial' ('A2/AD') strategy has figured prominently in the current defence discussion, particularly regarding ways in which it may be mitigated. Australian Defence academic Albert Palazzo reckons this to be the modern equivalent of the First World War's 'No Mans' Land', however greatly increased due to the reach of this 'A2/ AD' capability (Palazzo, 2019 ).

NATO continues to prepare for these challenges in a number of ways. First, as described above, is the increasing forward deployment of land forces. This has occurred, not only in the Baltics, but in the case of the US Army with a shift of substantial armoured units to bases situated further east. The recent re-positioning of a US Armoured Brigade Combat Team from Germany to Western Poland is a case in point. NATO has also attempted to counter Russian missile A2/AD with the deployment of its own missile systems through its eastern area of responsibility. The Black Sea region is shown below to highlight the Southeastern European region deployment of NATO intermediate range assets, particularly in Romania. Similarly, mobile defensive systems such as the Patriot missile have also been deployed in Poland, which is yet another 'frontline' NATO state. However, notwithstanding these measures, NATO's level of preparedness to counter the Russian missile threat is variable in nature: clearly there is too large an area for NATO to be able to protect its populations at large completely from Russian missile attack and its consequences. In this regard, Russia retains the initiative and as a defensive alliance, NATO is limited to reactive or retaliatory measures.

\section{Reinforcement, Sustainment, Movement, and Host Nation Support}

The issue of moving, receiving, staging, onward movement, and transit of NATO military forces from elsewhere in Western Europe and across the Atlantic is currently one of NATO's 
greatest current operational-level challenges and is a principal area in which NATO is expending considerable effort. In contrast with to Russia's considerable advantage in terms of geopolitical distance, NATO's responsiveness and rapidity in responding to threats on its eastern borders both from Western Europe and from across the Atlantic are considerably restrained. When compared to the Cold War situation of 40 years previously, logistic reinforcement and sustainment of NATO forces provokes a formidable list of current challenges and obstacles, mostly related to basic factors of time and distance and their effects on force projection. Whereas in 1983, NATO was able to deploy major logistic sustainment over 'micro'-distances, in 2021, similar logistic sustainment must now occur over 'macro' distances. This will be confirmed by a cursory examination of a map of NATO's current eastern area of operations, which is considerably greater when compared to the principal 1983 theatre of West and East Germany.

These current challenges include substantial changes in infrastructure arrangements which previously did not exist in the 1980's. As one example, railways are essential for moving items such as armoured vehicles over long distances: in 1980, most, if not all NATO state railways were state-owned. Today, this is no longer the case, and to move an asset across Europe may require contracts and memoranda of understanding to be previously negotiated with a large number of individual rolling stock companies and privatised rail system operators. One other example may be, say, the NATO Northern and Central European Pipeline Systems ('NEPS' and 'CEPS' respectively). These systems, which exist to the present day and remain under NATO control, were designed to provide a closed fuel supply system during the Cold War. With the extension of NATO eastwards, these now fall far short of being able to supply any main NATO defence east of the previous West German-East German border. In terms of being able to sustain the fuel needs of a conflict, they are as incomplete as the pre-war Maginot line.

NATO's key preparedness challenges in the area of Reinforcement, Sustainment, Host Nation Support, and Movement have included initiatives in the three key areas of legal and procedural issues, Transport infrastructure issues, and Coordination and Host Nation support issues. NATO seeks to enhance its capabilities in a number of areas. Legal processes, paperwork, customs checks quarantine, and documentation constitute one of the single greatest delays built into the movement of any military forces across national borders in Western Europe today. Much work is being undertaken with the European Union in facilitating movement through mobility hubs. The requirement for cross-border paperwork to facilitate movement, whilst not in itself representing a mission critical factor, does increase delays which may be turn out to be future critical:

timescales for completing the required paperwork are likely to be of the same order of magnitude as timescales for the movement itself and legal and procedural delays may have operational impact (Hodges at al, 2020)

Transport infrastructure issues are a less obvious restraint, but equally potentially mission critical. A common example in Central Europe is the current lack of load rating of bridges for military traffic. A US M1A1 Abrams Main battle Tank weights over 70 Metric tonnes- well beyond the capacity of many Central European Road bridges today. To compound the situation, most non-motorway bridges now no longer display weight ratings as they were required to during the Cold War. Another transport issue affecting NATO's military preparedness lies in the lack of north-south road networks as well as differences in rolling 
stock gauges. The lack of north-south road networks is seen in many former Eastern bloc countries and is one of the key issues that the 'Three Seas' initiative seeks to remediate. ${ }^{3}$ The issue of rolling stock infrastructure is reflected in differences in rail gauges between the Baltic states (who use the former Soviet narrow gauge) and Western Europe, from which reinforcements will need to travel.

Finally, a major hindrance to effective to cross-European theatre movement is the lack of coordination between multiple military and civilian national agencies. Unlike the Cold War situation, a major deployment of forces:

(now) requires the mobilisation of civilian strategic transport assets, and the infrastructure to receive and re-deploy those forces on arrival on European soil. It is not just about military preparedness; civil preparedness is equally important (Hill, 2019).

This was previously not the case, as NATO governments in the Cold War acted essentially as single points of contact for movement and sustainment: the widespread privatisation of transport assets had not yet occurred. The process of privatisation has increased the amount of liaison and coordination required substantially. In comparison to the Cold War, NATO preparedness in this area requires high level, complex interactions between a number of NATO and national military and civilian agencies. Like mobility discussed above, ongoing preparedness in this area is also being undertaken jointly between NATO and the EU through mobility initiatives negotiated through EU initiatives such as Permanent Structured Cooperation (PESCO). ${ }^{4}$ At a Joint Force level, NATO has commenced a number of initiatives at several levels in order to counter logistic vulnerabilities. In late 2017, two new NATO Joint Force commands were created and specifically tasked with coordinating movement of forces across Europe and the Atlantic. ${ }^{5}$ In addition, much work is being done at the operational level to exercise cross -border movement and coordinate host nation support. This work is being led by the NATO Multinational Logistic Coordination Centre (MLCC) based in Prague in the Czech Republic, which is primarily tasked with the enhancement of NATO logistic interoperability.

\section{Concluding thoughts}

This article has provided an analysis focussed on the strategic level, of key issues affecting NATO's preparedness to fight a conventional war against its most likely peer/ near peer adversary, Russia. The method employed has been to assess the preparedness of NATO, as a 'supranational' entity, applying the 'DIMEFIL' national instruments of power as benchmarks. This has been done by attempting to qualitatively assess the degree of power projection that NATO manifests in each 'supranational power domain' through the application of each component in the DIMEFIL construct ( With 'DIMEFIL' being the current most widely used conceptual framework for expressing the instruments of power comprising seven discrete

\footnotetext{
${ }^{3}$ For details, see: https://3seas.eu/

${ }^{4}$ For details, see: https://pesco.europa.eu/

5 Joint Support and Enabling Command (JSEC), based in Ulm, Germany, and Joint Forces Command, Norfolk (JFCNF), based on the east coast of the USA. JSEC and JFC-NF have very clearly differentiated areas of responsibility noting that with this action, both cross-European and Atlantic movement have been accorded high levels of priority within NATO.
} 
elements). The DIMEFIL construct of instruments of national power correlates directly to NATO's supranational capabilities and have been directly applied without modification.

In summary, the article has concluded that NATO's preparedness varies according to which specific instrument of power is being considered. In terms of the diplomatic, economic, and financial instruments of power, NATO is somewhat limited in its capability and consequently is limited in its ability to achieve high levels of preparedness. In addition, NATO currently has limited power application capability in the Intelligence domain. The classic intelligence functions of intelligence gathering, analysis, and dissemination, remain vested in NATO member states. Notwithstanding this, initiatives to develop and enhance collective NATO dissemination of intelligence are ongoing. In the Informational dimension of power, NATO possesses considerable capability, however, when compared to current levels of Russian power projection activity in this domain, some alignment of informational instruments of power with NATO strategic intent will be necessary if NATO's current posture in this area is to be more than reactive. NATO's current position on reactive cyber-activity is widely seen to be increasingly inadequate by many commentators, especially in the light of recent complex cyberattacks thought to have originated in the notorious Russian $\mathrm{GU}^{6}$ 'St Petersburg' hacker unit". Any change in NATO's procedures in this area with a view to enhancing preparedness will need to be coupled with a heightened collective resolve. This may include informational actions which NATO presently considers as inimical to its defensive nature such as cyberattacks. The principal risk is that if pre-emptive cyber activity should be undertaken, that this would almost certainly be interpreted by Russia as hostile action. These could then conceivably provide a pretext for aggressive Russian action leading to, for example, a limited incursion into the Baltic NATO states. The unintended consequences of a more robust NATO informational power projection stance will need to be considered very carefully indeed by NATO strategists.

In contrast, there is a sound basis for NATO in its expression of the Legal instrument of power. This is a direct consequence of NATO's solid foundations in international law dating from its 1949 inception. Legitimacy and legality are twin elements which remain much soughtafter pre-requisites for state action, on whichever 'side'. As evidenced by recent history, this does not have to be factual, as the key issue here is often not objective fact, but the provision of a plausible legal pretext for action. Russian 'lawfare' in Crimea in 2014 is a good demonstration of the application of these principles in support of Russian state action.

Finally, NATO's greatest capability for power projection lies in its ability to apply the Military instrument of power. This would seem obvious, given NATO's primary role as a defensive military alliance. Consequently, the military domain is one in which NATO is able to exercise the greatest degree of application to prepare and counter any peer/ near peer adversary. However, NATO's level of preparedness for this eventuality is currently incomplete and will remain so, given that a $100 \%$, 'perfect' level of preparation is probably unattainable. The Alliance's goal remains to maximise preparation, readiness, and achieve the highest possible level of risk mitigation to its fullest extent.

\footnotetext{
${ }^{6}$ The current acronym for the main military intelligence directorate of the Russian Federation is ' $G U^{\prime}$, differentiating it from its Soviet-era acronym of 'GRU', noting that the term represented by the acronym in Russian is the same.

${ }^{7}$ See: https://www.theguardian.com/world/2015/apr/02/putin-kremlin-inside-russian-troll-house. Even though this article is dated 2015 , the site is apparently (2020) still continuing to function.
} 
These final paragraphs would be an appropriate place to remind the reader of the Clausewitzian principles which underscore war's enduring nature. Whereas current events in 2021 have already demonstrated ongoing changes in the character of warfare, for example resulting from the impact of emerging technologies in recent conflicts. The July 2020 ArmeniaAzerbaijan conflict is an example of the evolving and changing character of war, demonstrated by the effect of the increasing use of both unmanned aerial systems in the form of swarming loitering munitions, and widespread employment of semi-autonomous battlespace systems. Clausewitz's 'enduring trinity', which comprises '...primordial violence, hatred, and enmity...chance and probability... and of its element of subordination, as an instrument of policy...' (Cole, 2020, p 43) continues to underpin the activity of war. These principles remain as valid today as when they were first expressed. This article has focussed on NATO action and the application of instruments of 'supranational' power, however with discussion of its most likely adversary Russia done strictly in the context of the NATO alliance. A truism holds that '...the enemy always gets a vote...'. If this discussion should shift its primary focus onto the adversary (Russia) rather than on the Alliance (NATO), an entire series of elements would then come into play with the distinct potential to alter outcomes. Put another way, none of this present discussion can account for the random, unpredictable events which will arise at every level of war, particularly those which are generated as a result of enemy action. Enemy (Russian) action will change the best laid plans of NATO and alter the course of events, upsetting the comfortable predictions of observers and commentators alike. Not only is it necessary to make estimates and account for Russian action and the circumstances governing those actions, but also to respond to novel and unexpected situations arising from blind, random, circumstance that have absolutely nothing to do with either side.

In conclusion, this writer holds that any question that attempts to quantify NATO's preparedness for fighting and winning a conventional war against Russia by applying a set of benchmarks ( such has been done in this article using the DIMEFIL instruments of power) will remain ultimately ...unanswerable. All analyses, whether ranging from the superficial and qualitative to the complex and quantitative, seek to predict the outcome of a future event which is essentially unknowable. Unfortunately, it would appear that any answer to the question of NATO's preparedness will only be derived empirically with all the cataclysmic and terrible results that this will entail.

Please note that the views expressed in this article are those of the author alone and should not be taken to represent the views of the Baltic Defence College, the Australian Defence Force or any other group or organisation.

\section{BIBLIOGRAPHY}

Bartholomees Jr J Boone (eds.), ' US Army War College Guide to National Security Issues, Vol II: National security policy and strategy', US Army War College, Carlisle, $5^{\text {th }}$ edition, June 2012, pp 47-48.

Boulegue Matthew, ' Five things to know about the ZAPAD 2017 military exercise' in Chatham House webpages, dated 20 Sept 2017, accessed via: https://www.chathamhouse.org/2017/09/five-things-know-about-zapad-2017-militaryexercise. 
Chamberlain N , speech broadcast by the BBC on 27 September 1938, retrieved from: https://www.bbc.co.uk/archive/chamerlain-addresses-the-nation-on-his-negotiations-forpeace/zjrigwx, on 12 Jun 2021.

Cole B, 'Clausewitz's wondrous yet paradoxical trinity: the nature of warfare as a Complex Adaptive System', in Joint Force Quarterly, $1^{\text {st }}$ quarter 2020, pp 42-49.

Connable B, Young S, Pezard S, Radin A, Cohen RS, Migacheva K, Sladden J, 'Russia's hostile measures: combatting Russian grey zone aggression in the Contact, Blunt, and Surge layers of competition', Rand Corporation, (Santa Monica, 2020).

Doran, Peter.B, 'Land Warfare in Europe: lessons and recommendations from the war in Ukraine', Centre for European Policy Analysis ( Washington DC 2016).

Dunlap Jr Charles 'Law and Military Interventions: Preserving Humanitarian Values in 21st Century Conflicts' in Conference Proceedings 29 November 2001, the Carr Centre for Human Rights Policy Harvard, Washington DC.

Durkalec Jacek, 'European Security Without the INF Treaty' in NATO Review, 30 Sep 2019, accessed via: https://www.nato.int/docu/review/articles/2019/09/30/european-securitywithout-the-inf-treaty/index.html

Freytag Von Loringhoven, A 'A New Era for NATO Intelligence' in NATO Review, dated 29 Oct 2019. Accessed on 3 Jan 2021 via: https://www.nato.int/docu/review/articles/2019/10/29/anew-era-for-nato-intelligence/index.html

Fukuyama Francis, 'The End of History?' in The National Interest, Summer 1989, No 16.

Gordon M.R, 'Russia has deployed missile barred by treaty, US General tells Congress', in The New York Times, 8 March 2017, accessed via: https://www.nytimes.com/2017/03/08/us/politics/russia-inf-missile-treaty.html , accessed 13 Feb 2021.

Gyori L, Kreko P, 'Russian disinformation and extremism in Hungary', The Warsaw Institute, Review, 16 October 2017, accessed from: https://warsawinstitute.org/russiandisinformation-extremism-hungary/ on 10 June 2021.

Hill Jonathan, 'NATO: Ready for Anything?' in NATO Review, dated 24 Jan 2019, accessed via: https://www.nato.int/docu/review/articles/2019/01/24/nato-ready-for-

anything/index.html

Hodges Ben, Bugajski Janusz, Doran Peter. B, 'Securing the Suwalki Corridor: Strategy, Statecraft, and Defense' in CEPA Analysis, Tallinn, July 2018.

Hodges Ben, Lawrence Tony, Wojcik Ray, 'Until something moves: Reinforcing the Baltic region in crisis and war' in ICDS Report (Tallinn 2020) dated 20 April 2020. 
IPSOS MORI-Kings College London report, unaccredited, 'Public perceptions of NATO', dated Dec 219, accessed via: https://www.ipsos.com/en-us/news-and-polls/NATO-Seen-As-ForceFor-Good-But-Support-is-Low

Johnson David, 'Zapad 2017 and Euro-Atlantic Security' in NATO Review, dated 14 Dec 2017, accessed via: https://www.nato.int/docu/review/articles/2017/12/14/zapad-2017-andeuro-atlantic-security/index.html, accessed 12 Feb 2021.

Lewis Donald, 'What is NATO really doing in cyberspace?', in War on the Rocks, https://warontherocks.com/2019/02/what-is-nato-really-doing-in-cyberspace/, dated 4 Feb 2019, accessed 13 Jun 2021.

NATO, Official texts, the North Atlantic Charter dated 4 April 1949. Accessed via: https://www.nato.int/cps/en/natolive/official texts 17120.htm.

NATO 2018 Brussels Summit Declaration dated 11 July 2018, para 13. Downloaded from: https://www.nato.int/nato static fl2014/assets/pdf/pdf_2018_07/20180713 180711summit-declaration-eng.pdf on 14 Feb 2021.

NATO, Text of the North Atlantic Treaty, dated 4 April 1949. Accessed via: https://www.nato.int/cps/en/natolive/official texts_17120.htm

Oskarsson, Kayerina, ' The effect of DIMEFIL instruments of power in the grey zone', , NATO Allied Command Transformation, (Norfolk 2017).

Palazzo A, 'Crossing 2000 Kilometres of Death', Land power forum, Australian Army Research Centre, 17 Sept 2019, accessed via: https://researchcentre.army.gov.au/library/land-powerforum/crossing-2000-kilometres-death, on 14 June 2021.

Petersen Phillip.A, Myers Nicholas, Baltic Security Net Assessment, Baltic Defence College (Tartu 2018), 2nd edition.

Schmidt Ulla, 'Advancing Stability in the Black Sea, a Special Report', from the Committee on the Dimension of Security, NATO Parliamentary Assembly, dated 7 Oct 2017, NATO Public Affairs.

Shaw, Malcolm, 'International Law, 8th edition', (Cambridge 2017), p 854.Simpson Priit,

'Martin van Crevald: I doubt whether Estonia can trust its Allies' in ICDS Commentary, dated 6 May 2016, accessed via: https://icds.ee/en/martin-van-creveld-i-doubt-whether-estoniacan-trust-its-allies/

SIPRI Yearbook 2020, Association of American Scientists. See: https://www.sipri.org/sites/default/files/YB20\%2010\%20WNF.pdf, downloaded 14 Feb 2021.

Sonne P, 'A Russian bank gave Marine Le Pen's party a loan. Then weird things began happening', Washington 28 Dest, $2018 . \quad$ See: https://www.washingtonpost.com/world/national-security/a-russian-bank-gave-marine-lepens-party-a-loan-then-weird-things-began-happening/2018/12/27/960c7906-d320-11e8a275-81c671a50422 story.html, accessed 10 June 2021. 
United Nations, Charter of the United Nations dated 26 June 1945. Accessed via: https://www.un.org/en/charter-united-nations/.

U.S. Department of Defense,' Summary of the 2018 National Defense Strategy of the United States of America', Washington, D.C., 2018, p.1.

Veenendaal M, Kaska K, Brangetto P, 'Is NATO ready to cross the Rubicon on cyber defence?' cyber policy brief, NATO Cooperative Cyber Defence Centre of Excellence (Tallinn 2016 ).

Voyger Mark, 'Russian Lawfare-Russian's weaponisation of international and domestic law: implications for NATO and policy recommendations', chapter in: NATO at 70 and the Baltic states:strengthening the Euro-Atlantic alliance in an age of non-linear threats, Baltic Defence College, (Tartu 2019). 